\title{
A study in matching the time and the names of Cyrus and Dhu al-Qarnayn
}

Mohammad Reza Besharati,

Member of the Scientific Association of Iranian Quran Miracle, Volunteer Researcher of the Holy Quran Miracle Research Institute of Shahid Beheshti University and PhD Student in Software Engineering, Sharif University of Technology

Dr. Hossein Shojaie

Associate Professor of Physics and Member of the Research Council of Professors of the Miracle Research Institute of the Holy Quran, Shahid Beheshti University

Dr. Alireza Talebpour,

Associate Professor of Computer Engineering and Head of the Miracle Research Institute of the Holy Quran, Shahid Beheshti University

\begin{abstract}
Dhu al-Qarnayn is one of the historical figures of Quranic stories, about whose identity and history various theories have been presented so far. The most prominent of these views are equated with prominent figures such as Cyrus of Persia, Alexander the Macedonian, the mighty kings of the Himyarite Kingdom, and even the Prophet Solomon. Evidence used in this research is: historical documents, documentary reports, hadiths, commentaries, testamentary evidence, ancient sayings, ancient geographical maps, linguistic evidence, mythological evidence and comparative literature, and evidence of the names of geographical places. According to the theory selected and presented in this article, Dhu al-Qarnayn is probably the Iranian Cyrus, which is consistent with the preferred theory of Allameh Tabatabai (RA) and some other contemporary commentators.
\end{abstract}

Keywords: Holy Quran, Dhu al-Qarnayn, Cyrus, Alexander

\section{Introduction}

The late Allameh Tabatabai, Ayatollah Makarem Shirazi, the late Dr. Shariati, the late Abolkalam Azad and the late Ayatollah Maaref are among those who have preferred the theory of Cyrus' Dhu al-Qarnayn to other theories about Dhu al-Qarnayn. Based on these theories, a research effort was made to examine the aspects of matching the time and the names of Cyrus and Dhu al-Qarnayn, which are presented below.

\section{History of Abu Rihan for Dhu al-Qarnayn}

Abu Rihan al-Biruni quotes the Jews in the book of Mas'udi's law as saying that there was an 111-year gap between the destruction of Jerusalem by Nebuchadnezzar II and the time of Dhu al-Qarnayn (probably the death of Dhu al-Qarnayn according to the Jews). According to Abu Rihan, however, Christians and Greeks put this distance at 311 years. If we consider the first estimate (111 years), then the period of Dhu al-Qarnayn will be almost comparable to the reign of Cyrus. If we consider the second estimate (311 years), then we come to the time of Alexander the Macedonian. Apparently, the people of Alexandria (some Christians and some Greeks) actually call Alexander the Macedonian Dhu alQarnayn and the founder of the city of Alexandria. On the other hand, it is said that the 
construction of Alexandria took 300 years. From the latter two cases, we can suggest that Cyrus started the construction of Alexandria and 200 years later, Alexander the Macedonian added it in his time.

In general, it seems that before Alexander the Macedonian, the ancient people (including the Jews) knew Cyrus as Dhu al-Qarnayn. After the reign of Alexander the Macedonian, some people confused Alexander the Macedonian, who was Alexander the Macedonian, with previous Alexander (Cyrus).

Many old and new Islamic scholars also emphasize that we had two Alexander and Alexander Dhu al-Qarnayn was before Alexander the Macedonian. Also, the name of Alexander the Macedonian is always associated with the Macedonian adjective, which indicates that another Alexander existed before him, and people have always associated the name of Alexander the Macedonian with the adjective Macedonian in order not to confuse the two.

\section{Pythagoras and the time of Cyrus Dhu al-Qarnayn}

Some consider Pythagoras to be one of the greatest mathematicians in history, who established philosophical principles and rules for mathematics and lived before Euclid, Aristotle, Plato, Archimedes and others.

He was in the time of Cyrus the Achaemenid and had made many trips to different parts of the world and in these trips he learned a lot and especially had an important stop in Egypt for teaching and learning.

On the other hand, according to Muslim narrations, Hermes is considered the father of mathematics, astronomy and wisdom. There are narrations from Muslims that Hermes is the same as Idris Thani (ie Elias the Prophet (PBUH)) whose Babylonian name was Hermes and he was a minister, assistant and companion of Dhu al-Qarnayn.

Some predecessors have considered Pythagoras and Hermes to be contemporaries of Alexander the Dhu al-Qarnayn. We now know that Pythagoras was a contemporary of Cyrus and lived a few centuries before Alexander the Macedonian.

Some predecessors have considered Pythagoras in the time of KayKhosrow. Since Kaykhosrow is probably the same as Cyrus (according to Abu Rihan), then we have a narration that Pythagoras and Cyrus were simultaneous, and in this way we can conclude that Kaykhosrow and Cyrus are the same.

On the other hand, Muslims consider Dhu al-Qarnayn to be the founder of the basic principles of logic. Idris and Dhu al-Qarnayn are also mentioned in the narrations as teachers and experts in astronomy, respectively.

From all this we can conclude that Pythagoras was one of the disciples of Hermes (Idris II) who in the time of Cyrus Dhu al-Qarnayn and his successors, was able to learn the science of wisdom, mathematics and logic from Hermes and then by establishing a circle Teach 
others (which later became a philosophical-mathematical school). So the historical evidence suggests that Pythagoras was at the same time as Hermes, and that the two lived at the same time as Cyrus the Great.

\section{El-Khader, Daniel and the time of Cyrus Dhu al-Qarnayn}

Another name for Khader, according to tradition, is Jeremiah (Hebrew equivalent for Hermes). Therefore, according to Islamic history and traditions, the servants of Dhu alQarnayn have been:

1. Elias (Idris Thani) PBUH. Some have considered Elias Thani as Khader and call him Khader Elias (AS).

2. Khader (Jeremiah, the same as Hermes) who was the cousin of Dhu al-Qarnayn. Some consider Uzair to be Jeremiah. Therefore, Khader, Uzair, Jeremiah and Hermes are probably the names of one person in different languages and titles.

3. Daniel the Prophet (pbuh)

Daniel (AS) is also known as one of the ministers of Cyrus. Various sources also consider Dhu al-Qarnayn and Daniel to be contemporary. Some ancient sources also consider Daniel to be the master of Dhu al-Qarnayn and his minister. Ancient historical as well as testamentary sources consider Daniel to be one of Cyrus' contemporaries, appointees, and apprentices. From the combination of these two points, it becomes clear that Dhu alQarnayn is the same as Cyrus and God knows best.

Both Elias, Hermes and Daniel are considered to be the leaders of the sages. Dhu alQarnayn himself was a sage. Therefore, the 4 sages were the pillars of Dhu al-Qarnayni's government. Ibn Arabi says that the four sages gathered under the dome of Arian (located in eastern of China and in the final east and its other name is KANGDEZ). According to another narration, KANGDEZ (Arian Dome) was built by Kaykhosrow (Cyrus). According to another narration, Zarathustra was martyred in KANGDEZ. According to another narration, Zarathustra was a student of Uzair (Khader). From all this it follows that Elias, Khader, Daniel and Cyrus had gathered under the dome of Arian (KANGDEZ).

According to ancient geography books, KANGDEZ was located near the far east, behind China, 90 degrees from the far west, on the ocean coast and on the border of old Iran and old Turan. From this and other evidence, it appears that the farthest west was the Galapagos Islands (90 degrees west of Greenwich) and the KANGDEZ was near the Bering Strait (180 degrees west of Greenwich, the Anyan Tyr region, or present-day Far East in Russia). There are now traces of several ancient monuments in the area.

Goshtasp (or Vishtaspa) and Cyrus Dhu al-Qarnayn

According to various evidences, Avestan and Shahnameh Goshtasp should be considered as another mythological-historical manifestation of the historical character of Cyrus. 
Goshtasp is considered to be the savior of the children of Israel from Babylon. This is also attributed to Alexander the Dhu al-Qarnayn (not Alexander the Macedonian). This was done by Cyrus according to ancient history and according to testamentary sources. Goshtasp is considered to be the most powerful, faithful and conquering kingdom in the world. Therefore, it can be concluded that Goshtasp is one of the narrations of the historical figure of Cyrus Dhu al-Qarnayn.

Kaykhosrow and Cyrus Dhu al-Qarnayn

Khader and Dhu al-Qarnayn (probably Cyrus) were also cousins and were both princes of their time. Dhu al-Qarnayn becomes the king and the khader is at his service. This khader is the second khader and should not be confused with Khader Akbar (who was a contemporary of Musa Kalim (as)). This second Khader is probably Khosrow. Later in the following centuries, from the combination of the characters of Cyrus and Khosrow, an epic character named Kaykhosrow is created by the people of the following centuries in their narratives. Abu Rihan al-Biruni in the book of Mas'udi's law states a narration that Kaykhosrow means the same as Cyrus.

Zarathustra, Houshang and the time of Cyrus Dhu al-Qarnayn

It is worth mentioning that Avestan sources consider Goshtasp to be a contemporary of Zoroaster and we said that Goshtasp is a narration of Cyrus. It is said that Goshtasp sent the divine teachings in different languages to the people of different lands and preached the divine teachings. It is possible that Cyrus prepared copies of the monotheistic teachings (a copy of the teachings of Abraham and Moses) which were in accordance with the language and subculture of each ethnic group. The religion of Zoroaster was the product of a special version of the Magi, and Zoroaster was probably one of these three people (Khader, son-in-law of Cyrus, Cyrus) or coincided with them or the combination of the characters of these three people. The reason for the similarity between the religions and myths of the Turkic, Indian and Magian nations is rooted in the same unified rule of Dhu al-Qarnayn.

One of the ancient pronunciations of Zoroaster may have been "Zara Torah", which can be considered as "Zoroastrian Torah" meaning "Torah of the Magi".

In Islamic sources, the name of the Prophet of the Magi is considered to be Jamasb, who was killed by the Magi. This name can be equated with Gaumatus the Magi (who was killed by Darius), who is considered by some to be the son-in-law of Cyrus and the same as Gautama Buddha.

It is narrated that in the book of Zarathustra, his followers were told to wait for the owner of the red camel (ie the Holy Prophet of Islam(PBUH)) in 1000 years after me. Therefore, 
the time of the emergence of Zoroaster can be estimated about 2400 years ago, which is close to the time of Cyrus.

According to their historical evidence, a group of Orientalists have considered the time of Zoroaster to be contemporary with Cyrus and Darius. According to historical evidence, Cyrus was a united and faithful person.

According to the testamentary evidence, Cyrus served and accompanied the prophets of Bani-Israel. There is evidence that Idris Thani (AS) (who is the same as Hermes and the same Elias (AS) is the attendant of Khader or Khader himself) was the mentor and attendant of Cyrus.

From the collection of historical, religious, national, testamentary narrations, etc., it can be suggested that: Zarathustra was probably a contemporary or a student of Idris II (AS) who had the task of translating and propagating the teachings of the Torah of Moses (AS) among the Magi and He was supported by Cyrus, and in this way, he was martyred by the false front and in their invasion, in a city called Balkh in ancient East Iran near Northeast Asia, and not Balkh in Central Asia. There is a possibility that Cyrus and Zarathustra are the same.

There is also evidence that the word Zarathustra in ancient Iranian texts (in addition to the name of the book, the name of religion and the name of man) is a symbolic name to refer to the "Abrahamic prophecy ending in the end of the messengers." Therefore, we see that the grandson of Zarathustra is martyred and one of the sons or grandsons of Zarathustra is the savior of his apocalypse. Therefore, based on this, Zarathustra can also be considered as the result of a combination of the personalities of the sages of Cyrus Dhu al-Qarnayni. So the word Zoroaster is related on the one hand to monotheism, on the other hand to the Torah. on the one hand to Cyrus and on the other hand to the prophecies of Abraham and Muhammad (PBUH). Therefore, as a whole, the word Zarathustra can be considered as one of the innovations of the time of Cyrus and has a reference to monotheism, prophecy and Imamate.

From the comparison of the meanings of the national stories of the Middle Eastern nations with the meanings mentioned in the religious texts, it seems that aspects of the character of Houshang and Hermes Babylon should be sought in Dhu al-Qarnayn and Idris Thani (as), respectively (the same as Elias the Prophet).

It is said that Houshang guided each people to wisdom according to their own tradition. On the other hand, it seems that Houshang Pishdadi is, in some ways, a retelling of Kaykhosrow Kiani. Where both take Kin (Revenge) of their murdered fathers from the evildoers and rule over 7 countries. Since Kaykhosrow is probably a narrative of Cyrus' life in Persian mythology, it can be suggested that aspects of Houshang's character are similar to those of Cyrus. 
Pythagoras, on the other hand, is considered a disciple of Hermes of Babylon and a contemporary of Kaykhosrow (and a contemporary of Cyrus).

On the other hand, Elias the Prophet (PBUH) along with Khader (PBUH) are considered to be the servants of Dhu al-Qarnayn.

In the hadiths, astronomy has been attributed to Idris (AS) and Dhu al-Qarnayn (respectively in terms of education and skills).

Some have considered Hermes to be the same as Dhu al-Qarnayn, who was the proverb of three blessings: he was a prophet, a sage and a king. From this quote, we can at least suggest the simultaneity and contemporaneity of Hermes and Dhu al-Qarnayn. Others have considered Hermes the Wise as the minister and teacher of Dhu al-Qarnayn.

From all these cases, it can be suggested that Houshang, Cyrus and Dhu al-Qarnayn were a single historical figure. It can also be suggested that Hermes of Babylon and Elias the Prophet (Idris II) were a single historical figure.

On the other hand, some have gathered between the character of Hermes and the Buddha. On the other hand, we know that the Buddha was almost contemporary with the time of Cyrus.

According to the teachings of the Testament, Dhu al-Qarnayn is the one who spreads the name of God and the teachings of theology in the east and west of the world.

Among these evidences, it can be suggested that: Dhu al-Qarnayn or Cyrus together with Elias Nabi (Idris Thani) (AS) mark a cultural-theological-epistemological revolution in the sixth century BC. Among the members of this school are the Greek-Egyptian Pythagoras, the Persian Zoroastrian and the Nepali-Indian Buddha. Shinto religion also been influenced from this cultural revolution, Later. Over time, distortions, changes, and alterations make these rituals different in details. So Dhu al-Qarnayn (probably the Iranian Cyrus) is the one who spreads the name of God and monotheistic theology in his time in the East and West of the world. And God knows.

The prophet Daniel (pbuh) is considered to be one of the disciples of Idris Thani (that is, one of the disciples of the prophet Elias). It is narrated that Daniel the Prophet (PBUH) was the minister of Cyrus. Some have claimed that Hermes or even Idris II was the same as the prophet Daniel. From these sayings, it can be deduced that Cyrus Dhu al-Qarnayn was probably one of the collaborators of the Prophet Daniel (pbuh) in this revolution.

\section{Alexander Rumi, Dhu al-Qarnayn and Cyrus}

Some ancient Greek historians have named the family and tribe of Cyrus "Ionian". In some versions of Homer's Iliad, the famous author, Cyrus the Achaemenid, is considered to be 
originally from the ionian family ${ }^{1}$ (the Iliad was written several centuries after Homer). In Khamseh Nezami and some other sources, we are talking about an Iranian Alexander who speaks Persian and has a Kiani hat and is Iranian and at the same time, is attributed to the ionian adjective.

Cyrus's grandmother was from Lydia and probably from the Ionians. Therefore, the fact that Cyrus is considered to be from the tribe of Ion may be due to this, and it may be that Ion is a metamorphosis of Anyan and Anshan (the name of Cyrus' fatherland).

In Ajami-Iranian stories and tales, Dhu al-Qarnayn 's father is considered Persian and his mother ionic. Cyrus's father was also Persian and his mother's mother was from the Lydian ion tribe.

Ions have been considered the source of wisdom. Therefore, the mother tribe of Dhu alQarnayn has been the source of wisdom. In Islamic traditions, Khader is also considered the cousin of Dhu al-Qarnayn. So Khazer must have been from the ion tribe. Cyrus's mother is also known as Kalimi and belongs to the Ionian tribe. The lineage of ions has been passed on to Isaac the Prophet (PBUH). The lineage of the Persians and Dhu al-Qarnayn has also been passed down to Isaac the Prophet (pbuh).

From all these cases, it can be suggested that first of all, Cyrus is Dhu al-Qarnayn. The Alexander Ionian, whose father is Persian and his mother is Ionian (please do not confuse him with Alexander the Macedonian, because according to some ancient elders, there was a distance of about 200 years between them) is Cyrus: his father was Persian and his mother was from the Ionian tribe.

A book from the 12th century (belonging to a person named Abdul Hussein Hosseini Khatunabadi) quotes from another book from the 9th century called Lab al-Tawarikh that the kings of Kianian were 10 people and one of them was called "Alexander Ibn Dara nicknamed Dhi Al-Qarnayn". This document is important because it shows that, first of all, the kings of Persia were also nicknamed Dhi Al-Qarnayn. Secondly, because Dara is in this name and because it is known as Kianian, then it must be from Achaemenid. Thirdly, its combination with other evidences shows that the literal meaning of the word Alexander is equivalent to the word Cyrus and the meaning of Alexander Ibn Dara is Achaemenid Cyrus. So with this evidence we can say that one of the chroniclers of the 9th century has called Cyrus as Dhu al-Qarnayn. And God knows.

\footnotetext{
' According to Parnian Hamed, a contemporary researcher and author of the book "That Alexander of Iranian History is not a Greek Alexander." The Iliad also speaks of an ethnic group called the Achaeans, which some non-Iranian scholars have equated with the Achaemenids. The lliad also mentions an island in the Aegean called Scyros (modernday Skyros) from which archaeologists have discovered coins with the design of the Kiani logo from the fifth century BC. The body of evidence suggests that there was some kind of kinship between some Achaemenids and some Greeks.
} 
In the sixth century, Ibn Jawzi, quoting Abdullah ibn Shudab, considered Khader (AS) as one of the sons of Persia (ie Iranians) and considered him in the time of Fereydoun. He points out that some people consider Dhu al-Qarnayn as Fereydoun and consider the two as one. Some other sources have listed Cyrus and Fereydoun as one. Also, many Islamic historians have considered Khader as the cousin of Dhu al-Qarnayn (meaning Khader II and not Khader Akbar who was in the time of Moses). From all these cases, another way is obtained for Cyrus to be a Dhu al-Qarnayn. And God knows. The late Allameh Tabatabai, Ayatollah Makarem Shirazi, the late Dr. Shariati and the late Ayatollah Maaref are among those who have preferred the theory of Cyrus' Dhu al-Qarnayn to other theories about Dhu al-Qarnayn. In the Asar Al-Balad and Akhbar al-Ibad, Zakaria Qazvini of the 7th century, which is one of the most important books on the heritage of Islamic geography, mentions "Iskander Ibn Dara Ibn Bahman" from the Persian monarchs.

We argued that this Alexander ibn Dara ibn Bahman is Iranian and he means the same Cyrus for various reasons (and is not Greek or Macedonian and should not be confused with Alexander the Macedonian). He is the same as Dhu al-Qarnayn and Alexander the ionian or Rumi (late Ayatollah Lari Rokni (RA) points out in an article that it should not be confused between Alexander Dhu al-Qarnayn and Alexander the Macedonian).

According to Ajami histories and then through them Islamic histories, the lineage of Dhu al-Qarnayn is as follows: Alexander Ibn Darab Ibn Bahman Ibn Esfandiar Ibn Goshtasp We know that Bahman and Goshtasp are mythological narratives of Cyrus. Therefore, according to Ajami and Islamic histories, Alexander Dhu al-Qarnayn is a descendant of Cyrus. But why is this so? There is probably a confusion between the narratives of the lives of Alexander I (Cyrus) and Alexander II (Macedonian), and from the heart of this confusion comes the myth of the "Iranian Rumi Alexander", in addition to the fact that this myth is highly consistent with the life and characteristics of Cyrus.

Therefore, the report of Dhu al-Qarnayn being Cyrus has reached us through Ajami chronicles, only he has been assumed to be the grandson of Cyrus (and not Cyrus himself). The reason for this mistake is the confusion of the time of Cyrus with the time of Alexander the Macedonian. So the meaning of the Persian Rumi Alexander (which we know is not the same as Alexander the Macedonian according to the scholars of ancient times) is Cyrus. It seems that the confusion between these two Alexanders caused a confusion between "the first teacher" or "Hermes" or "Elias the Prophet (PBUH)" with "Aristotle of Greece". Because it seems that the prophet Elias (AS) was along with the first Alexander (Cyrus) and was his teacher and encourager, and his Babylonian name was Idris and his other name was Hermes, and according to Islamic history, he is also the first teacher of wisdom. But 
between the real Dhu al-Qarnayn (ie, Alexander ibn Dara ibn Bahman of Iran, who means Cyrus) and his teacher (who was the prophet Elias), there is a false confusion with the false Dhu al-Qarnayn (ie, Alexander the Macedonian of Greece) and his teacher (who was Aristotle or Aristotle). So the riddle of the dual works of the first teacher is also solved: the part of philosophy and wisdom and the works attributed to Aristotle, which agrees with monotheism and Islamic teachings (like the science of logic) ends with the real first teacher (ie Elias the Prophet). But what is attributed to Aristotle which is related to polytheism and infidelity, have its roots in the school of the Greeks and the wrong Dhu al-Qarnayn. It is very important to know that they confused between our Dhu al-Qarnayn with Alexander the Macedonian and they also confused between Elias the Prophet (PBUH) and Aristotle the Greek. And of course, such problems occur naturally after centuries and the burning of Achaemenid books by Alexander the Macedonian, and God knows best.

Therefore, we have two Alexander in history:

1- Achaemenid Cyrus or the Rumi ionian Alexander who was from the side of the Persian father and from the side of the ionian mother, About 2500 years ago. His Persian name was Cyrus and his Ionian name (which gives the same meaning) was Alexander. He ruled for more than 33 years. It took over the west and east of the world, and he is probably the Dhu al-Qarnayn. He built many cities and was kind to the defeated nations. He was the beloved of the monotheists and the prophets of his time, and we even have a prophetic hadith from Prophet Mohammad (PBUH) in acknowledgment of his true faith.

2. Alexander the Macedonian, whose father was Macedonian and dates back to about 2300 years ago. Occupied parts of Asia and Egypt. He ruled for only 13 years. He destroyed many cities (including Qom and Persepolis).

\section{Names and titles of Cyrus Dhu al-Qarnayn}

Alexander is a Greek word whose ancient European equivalent is Alisaunder. If we consider this form as an undistorted form of the original Indo-European word, then it can be considered as consisting of two components "Ali" and Saunder.

The word Ali in ancient Eurasian languages meant height, peak and greatness. Because the languages of ancient Europe belong to the Indo-European language family, and because Indo-European languages have Eurasian roots, the word Ali in Alisaunder can be considered the same as the word "excellent" in some ancient Eurasian languages. Hence the literal meaning of Alexander: high guard, mountain guard or high-ranking warrior. These meanings are in line with the meaning of Dhu al-Qarnayn: because the Qarn also means height.

About Saunder or Zander: 
1- Everyone agrees that it means "defender". But it is known (purely by conjecture apparently and without reason) to be abbreviated to the word Alexander.

2- In Scots (which is one of the languages with the word Saunder), one of the meanings of Sand is considered to be "Clear Out" meaning removal, which is appropriate for the meaning of "Kandan" in Persian languages. It can be suggested that this sand and xand come from the Iranian-European origin of "Kand" and Zander and Alexander mean the same word "Kandar" which is also mentioned in Shahnameh. In Shahnameh, Kandar was the title of a Slavic hero.

Kandavar is another word that is mentioned in Shahnameh and it also means hero.

So Kander, Zander, and Alexander mean "the one who removes enemies and obstacles." It means a strong hero and fighter.

The theory is that "Ali Saunder" was an ancient Eurasian name meaning Dhu al-Qarnayn, which was later given to a son by a Macedonian mother and father, and Alexander became Macedonian.

Therefore, the name of Alexander or Ali Sauder is an earlier name and dates back to before the Macedonian king, and its literal meaning is similar to the literal meaning of Dhu alQarnayn.

Ibn Kathir has narrated in Al-Badaya and Al-Nahaya that Alexander was two people, and Alexander I was a believer and Alexander II was a person who had a country to open (i.e. conquest the Persia and Egypt).

The late Allameh Hassanzadeh Amoli (RA) considers Alexander Dhu al-Qarnayn to be different from Alexander the Macedonian and related to the centuries before him.

Even now, there are names in Turkish such as Qooch Ali, which can indicate the Eurasian origin of the word Ali and Aali in Turkish.

So far, it turns out that the word Ali is an old international word. The words "Ali" and "excellent" exist in Turkish, Mongolian, Arabic, Norse, some Indians and Aryan languages, and in these languages they mean "high", "mountain", "high", "excellent quality" and such meanings.

We have a hadith that Imam Ali (as) considers himself the Dhu al-Qarnayn of the nation of the Prophet (PBUH). Was this proportion also in the name, and did the name of Dhu alQarnayn, in its Eurasian form, have the words "excellent" or "Ali"? And God knows.

Currently, the highest peak in Alaska is called Denali, which can be considered a metamorphosis of "High Peak" or "Mount Ali". In Alaska, it is customary to name people after peaks. For example, there is the summit of St. Elias in Alaska.

In any case, the choice of words in the Holy Qur'an is so convincing that one can claim the miracle of words in the Holy Qur'an, and God knows best.

But how do the words Cyrus and Alexander mean the same thing? 
Cyrus $=$ Ko + Ro $=($ king, hero $)+$ high

Alexander $=$ Alexander $=$ Aali Zander $=$ Aali Kander $=$ Aali + Pahlavan

Ko means king and hero. "Ro" means high-ranking.

The word Kandar is mentioned in Shahnameh and is the name given to Pahlavan by the people of the west. Its Iranian equivalent is Kandavar and Gudarz. Therefore, the words Cyrus, Iskandar, Alexander and probably Ali Goodarz all have the same meanings and mean a high king or a high warrior or a mountain warrior.

The Yemeni words "Sa'b" and "Harith al-'Ali" are probably equivalent to the HamiriYemeni form of "Cyrus".

\section{Other titles of Cyrus Dhu al-Qarnayn}

Koi Vishtasp or Goshtasp is a powerful king of Kiani who supported Zarathustra and defeated Old Turan. There is evidence that some aspects of Goshtasp's character are similar to those of Cyrus.

Among the meanings for the name "Vishtasp" are wild dog or tiger. It probably means the same Vista (Tavis, Tavos) and a kind of Simorgh or Shirdal.

From all these cases, it can be suggested that one of the titles of Cyrus was Simorgh (heavenly king for the earth).

Therefore, the horn in the word Dhu al-Qarnayn can also be referred to as Simorgh: a mythical creature that possesses all the natural powers of wings, horns, crowns and forks. Therefore, his name is in different languages: Cyrus, Khosrow, Alexander, Iskandar, Aligudarz, Alisaunder, Saab, Harith Al-Ali.

His titles are in different languages: Dhu al-Qarnayn, Vista, Vishtasp, Simorgh, Artakhor (Shah Adel).

Perhaps the original name of Cyrus was "Dhu al-Qarnayn". The Greek historian Strabo says that "Cyrus's original name was Agradates, and after the conquest of Babylon, he chose the title of Cyrus."

But what does Agradates mean?

Agradates consists of two parts: Agra + Dates.

Agra may be the same as "Arta" or "Arte", which means "just". Dates also consists of two parts, $\mathrm{Da}+$ TeslTis

$\mathrm{Da}=$ has

Tis $=$ sharp $=$ Qarn and horn

So,

Datis $=$ Dhu al-Qarnayn, God knows best.

And Agradates = Dhu al-Qarnayn Adel . 
A better suggested derivation for the ancient Persian name "Agradates":

Agra $=$ captivating, has

$\mathrm{Da}=\mathrm{Daw}=$ Two

TesıTis $=$ sharp, horn

so:

Agradates $=$ two horns $=$ Dhu al-Qarnayn

The people of Khatai (northern China) say in their history (narrated to us by a man named Banakati 700 years ago in the book History of Banakati) that: a king named Juro Dunk (Dunk was a family name or title and other members of this dynasty also had this title. Hence the name of this king is called "Juro"), established the unit of Farsang. And, in his time the first prophet of the Khatai and Chinese tribes, named "Shamkuni Barkhan" appeared. Juro Dunk, the just and blessed king, had three sons who ruled after him.

Our current evidence from Herodotus and others also shows that the Farsang was invented by the Persians during the Achaemenid period. Zoroaster and Buddha both appeared during the Achaemenid period. The Achaemenid king who was just and his three sons ruled after him was Cyrus (Berdia, Cambyses and Gaumatus the Magi, who was the third adopted son and his son-in-law).

From this evidence, it can be suggested that Juro Dunk, or Juro, is a Khatai version of the name of Kuro or the Achaemenid Cyrus.

Juro is said to have defeated the king of the land of Jizkuh in eastern Khata (while the defeated king had overdosed on wine).

The same story is told by the Greeks about Cyrus's war trick to defeat the Masagets. When the Massages consumed too much wine, they were attacked by Cyrus's troops.

The same story was narrated by Marco Polo about the defeat of one of the kings of the eastern lands of Khatai.

From all these cases, which are independent reports of the three nationalities of Iran, Greece and Khatai about the ancient history of the far east of Asia, it can be concluded that the story of Cyrus's expeditions in the form of Juro Dunk is recorded in the history of Khatai, God knows best.

It should be noted that Shamkuni is a correction of the name "Shakmoni" or "Shakmoni", which some have considered him as the Buddha.

In the legend of the people of southern Britain, the wrestling of a king called "Corineus" or "Corineus" is mentioned with a giant named "Gog Magog". This king is considered the founder of the dynasty in the south of Britain. 
In a medieval European map (15th century AD), the land of Gog and Magog and its wall are depicted at the eastern end, and the collection of Gog and Magog and their confinement is attributed to a king of Persian called the "righteous ruler" Artaxor . This is probably another form of ArtaKuro or "Cyrus the Righteous".

The map above shows that a king named Artaxor, who was the king of Persia (Persia), imprisoned Gog and Magog in a prison in the northeastern part of Asia. Ibn Nadim has considered Artakhor (Artakht, meaning the same as Artakor) as Goshtasb. Goshtasb is another name for Cyrus (in the sources of Ajami chronicles). The sum of these three propositions (one from Europe, one from Ibn Nadim, and one from Ajami chronicles) is that Cyrus, king of Persia, imprisoned Gog and Magog at the northeastern tip of the Asian lands. So according to this historical document, Dhu al-Qarnayn is the same as Cyrus. And God knows.

In the 13th century Psalter World Map, the city of "Cyrus" (city of Cyrus) is drawn in a place where in other old European maps, the Alexander Dam (the name of Dhu al-Qarnayn Dam in European maps) is drawn. .

In Turkish mythology, Oghuz Khan is the name of a mythical person who was a monotheist and a god-worshiper and became the owner of the East and the West of the world and built a barrier in the land of darkness to ward off evil. He can be compared to Dhu al-Qarnayn. $\mathrm{He}$ (Oghuz Khan) is also mentioned in Mongolian myths: "According to Mongolian myths, the Mongol ancestors fought against Oghuz Khan's army and Oghuz Khan's army won. Two brothers from the Mongols were able to escape the battle and went into a mountainous place with a steep slope ("Ergenekon" or "Ergeneqon"). They were imprisoned there for 400 years and their generation multiplied. Then they were able to open the way out by smelting iron in the place of an iron barrier and get out of the 400 -year-old prison, and they are the Mongols".

\section{References}

- The Holy Quran

- Almizan fi Tafsir Al Quran

- Al- Muqaddimah, Ibn Khaldun

- Ancient Greek, Roman, European, Arabic-Islamic, Persian, Russian, Armenian, Jewish, and Turkish maps

- Homer's Iliad and Odyssey

- Testamentary sources

- Old history books

- Old geography books

- Old Zijs 
- Wikipedia, Britannica, Iranica, the Great Islamic Encyclopedia and other encyclopedias

- NoorLib Online Library

- "Elite and Quran Mining" Network, http:Ilqelnet.coml.

- Hamed, Parnian, "That Alexander of Iranian history is not a Greek Alexander", Avijeh Publishing, 2011.

- Achaemenid History Book by Pierre Brian.

- Tolman, Herbert Cushing. Ancient Persian Lexicon and the Texts of the Achaemenidan Inscriptions Transliterated and Translated with Special Reference to Their Recent Re-examination, by Herbert Cushing Tolman... American Book Company, 1908. 